\title{
Komunikasi Seni Hadrah Majelis Ahbaabul Musthofa Yogyakarta
}

\author{
Nida Ma'rufah \\ UIN Sunan Kalijaga Yogyakarta \\ Email : nidatmg@gmail.com
}

\begin{abstract}
Ahbaabul Musthofa has a great influence on the development of da'wah in Special Region of Yogyakarta. This assembly has a wide range of audience includes people from all districts. In addition, the hadrah group, who holds important role in the Ahbaabul Musthofa assembly, has high clock flown on the national events with a famous munsyid from Solo, Central J ava, Habib Syaikh Assegaf. That's why Ahbaabul Musthofa hadrah grup is still exist today, even become the main reference for most hadrah group in Special Region of Yogyakarta. As a medium of da'wah, hadrah in the Ahbaabul Musthofa assembly certainly not only become an entertainment in the middle of recitation, but also become a meaningful ritual, which is manifested in symbols.

Through ethnographic approaches and symbolic interaction theory, researcher tries to find symbols used in the hadrah and explore the meaning contained therein. The result shows that the hadrah in the Ahbaabul Musthofa assembly not only serves as entertainment, but also triggers increased love of the audience, especially Syekher Mania, to the prophet Muhammad SAW. More than that, these symbols contain more deep meaning, such as a symbol of self-worship to God through fun worship, a symbol of strong faith, an atmosphere of joy, peace of mind, simplicity, sincerity, and strong determination in worshiping to Allah.
\end{abstract}

KEYWORDS: Hadrah, symbols, meanings of hadrah symbols, Ahbaabul Musthofa Yogyakarta

\section{ABSTRAK}

Majelis Ahbaabul Musthofa memiliki pengaruh yang besar dalam perkembangan dakwah di Daerah Istimewa Yogyakarta. Majelis tersebut memiliki cakupan jamaah yang luas yaitu meliputi masyarakat di seluruh kabupaten di DIY. Di samping itu, kelompok seni hadrah yang berperan penting dalam majelis Ahbaabul Musthofa, memiliki jam terbang show yang tinggi di kancah nasional bersama munsyid kondang asal Solo, Jawa Tengah, Habib Syaikh Assegaf. Maka, tidak heran jika kelompok seni hadrah Ahbaabul Musthofa hari ini masih eksis, bahkan menjadi rujukan utama bagi sebagian besar kelompok hadrah di DIY dalam mengembangkan seni hadrah. Sebagai media dakwah, tentu seni hadrah pada majelis Ahbaabul Musthofa tidak saja menjadi hiburan segar di tengah kajian, tetapi juga menjadi sebuah ritual yang sarat akan makna, yang termanifestasi ke dalam simbolsimbol.

Melalui pendekatan etnografi dan teori interaksi simbolik, peneliti mencoba mengungkap simbol yang digunakan dalam seni hadrah majelis Ahbaabul Musthofa dan menggali makna yang terkandung di dalamnya. Hasil penelitian menunjukkan bahwa seni hadrah pada majelis Ahbaabul Musthofa tidak hanya berfungsi sebagai hiburan, tetapi juga menjadi pemicu bertambahnya rasa cinta pada jamaah khususnya Syekher Mania terhadap Nabi Muhammad SAW. Lebih dari itu, simbolsimbol tersebut mengandung makna yang lebih dalam, di antaranya sebagai simbol penghambaan diri kepada Allah melalui ibadah yang asyik, simbol keimanan yang kuat, suasana sukacita, ketenangan pikiran, kesederhanaan, ketulusan, dan tekad yang bulat dalam menghamba kepada Allah. 


\section{Pendahuluan}

Islam hadir melalui perantara Nabi Muhammad SAW. untuk menjadi petunjuk bagi seluruh umat manusia. Sebagai petunjuk, Islam perlu diserukan kepada setiap insan melalui jalan dakwah. Dengan dakwah, Islam tidak sekedar menjadi tuntunan umat, tetapi juga rahmat bagi seluruh alam dan memberikan kesejukan bagi umat manusia. Dakwah merupakan suatu bentuk komunikasi. Terbukti antara dakwah dengan komunikasi memiliki unsur-unsur yang sama, seperti yang disebutkan dalam teori Lasswell yang sangat terkenal yakni Who (da'i)-says what (pesan dakwah/ alquran, hadits)-to whom (mad'u)-with what channe/(media dakwah) - effect (perubahan pada mad'u). Dalam menghantarkan pesan dakwah da'i kepada mad'u, alquran dan hadits menjadi sumber yang paling utama. Penyampaiannya pun dilakukan baik secara verbal maupun non verbal. Adapun pesan non verbal biasanya tampil dalam bentuk simbol atau lambang.

Tujuan dari dakwah adalah untuk mengubah sikap, pendapat, atau perilaku orang lain yang lebih baik sesuai ajaran Islam, baik langsung secara lisan maupun tidak langsung melalui media tertentu (Wahyu Ilahi, 2010:26 ). Dalam mencapai tujuan tersebut, ada beberapa metode yang Nabi Muhammad SAW lakukan dan ajarkan kepada para sahabat dalam berdakwah. Metode ini meliputi hikmah (kebijaksanaan), mauizah hasanah (pelajaran yang baik), dan mujadalah bi alahsan (diskusi dengan baik), yang mana ketiga cara ini tersurat dalam QS. AnNahl: 125, yang berbunyi:

Artinya: "Serulah (manusia) kepada jalan Tuhanmu dengan hikmah dan pengajaran yang baik, dan berdebatlah dengan mereka dengan cara yang baik. Sesungguhnya Tuhanmu, Dialah yang lebih mengetahui siapa yang sesat dari jalan-Nya dan Dialah yang lebih mengetahui siapa yang mendapat petunjuk."(Departemen Agama Rl, 2011:281)

Itulah tiga cara yang dicontohkan oleh Nabi dalam mendakwahkan Islam pada masanya. Namun, selain tiga cara yang telah disebutkan, dakwah juga dapat dilakukan dengan beberapa metode lain, yakni memberi kabar yang menyenangkan, menggunakan sarana baru yang dianggap maslahat, menyentuh jiwa mad'u, mengundang kaum kerabat sambil makan dan minum, pendekatan keluarga, pidato terbuka, dan hijrah (Abdul Azis, 2006:19). Pada dasarnya, pesan dalam komunikasi lebih mudah diterima oleh komunikan ketika 
pesan tersebut sampai ke hatinya. Dalam upaya agar pesan dapat menyentuh jiwa mad'u, dakwah bisa dilakukan dengan menempuh jalan alternatif, yaitu melalui seni.

Seni menjadi suatu metode dakwah yang sudah terbukti keberhasilannya dalam menyentuh jiwa mad'u. Jika kita mengingat, kangjeng Sunan Kalijaga sendiri menggunakan syair-syair dan tembang untuk menarik hati masyarakat, dan terbukti hal ini dapat meyakinkan mad'u untuk masuk Islam. Adapun dalam suatu kesenian yang digunakan untuk berdakwah, tentunya terdapat simbolsimbol yang merepresentasikan nilai-nilai religiusitas sebagai pesan dakwah. Bagi pecinta karya seni, pesan dakwah jenis ini lebih banyak membuatnya berpikir tentang Allah SWT. dan makhluk-Nya, lebih daripada ketika mendengar ceramah agama (Moh Ali Aziz, 2016: 330). Dr. Yusuf Al Qardhawi dalam bukunya, Seni dan Islam, menyatakan bahwa, Islam sebenarnya menghidupkan rasa keindahan (estetika) dan mendukung kesenian, namun dengan syarat-syarat tertentu, yakni jika kesenian itu membawa perbaikan dan tidak merusak, membangun dan tidak menghancurkan (Yusuf Al-Qardhawi, 2000:11). Menurutnya, seni atau kesenian merupakan perkara yang sangat penting karena berhubungan dengan hati dan perasaan manusia. Seni berusaha membentuk kecenderungan dan perasaan jiwa manusia dengan alat-alat yang beraneka ragam dan merangsang, seperti alat-alat yang dapat didengar, dibaca, dilihat, dirasakan maupun dipikirkan. Dari uraian di atas, dapat disimpulkan bahwa pesan dakwah yang disampaikan melalui seni lebih mudah diterima dan dipahami oleh mad'u dibandingkan dengan cara yang lain. Harapannya, nilai ajaran Islam yang terkandung dalam pesan dakwah dapat diaplikasikan oleh mad'u ke dalam perilaku sosial budaya dan keagamaanya sehari-hari.

Apabila kita amati, hingga kini di Daerah Istimewa Yogyakarta masih kental dengan kegiatan keagamaan berbasis kesenian musik. Salah satunya yang tengah merebak dan digandrungi oleh masyarakat muslim Yogyakarta adalah seni hadrah. Di kabupaten Sleman sendiri, setidaknya terdapat 86 grup kesenian musik Islami yang secara resmi terdaftar di Kantor Kementerian Agama Kabupaten Sleman. Grup-grup ini terdiri dari grup hadrah, grup kasidah, dan beberapa majelis salawat (Kantor Bimas Islam Kementerian Agama Kabupaten Sleman Yogyakarta: 2018). Di samping itu, di kabupaten Sleman sendiri kerap 
dijumpai berbagai event perlombaan yang meliputi hadrah, kasidah, rebana, gambus, akustik, serta banyaknya penyelenggaraan majelis salawat dan zikir yang sifatnya insidental, sehingga tidak tercatat di Kantor Kementerian Agama Kabupaten Sleman (Suddarsana, 2018). Data tersebut menunjukkan bahwa ternyata seni hadrah memiliki peranan penting dalam perkembangan dakwah Islam di Yogyakarta.

Berkaitan dengan seni hadrah, rutinan majelis Ahbaabul Musthofa merupakan satu dari sekian banyak majelis zikir dan salawat (melibatkan seni hadrah) yang kerap diselenggarkan di Kabupaten Sleman. Jamaahnya terdiri dari masyarakat umum se-DIY dan didominasi oleh komunitas Syekher Mania (Pecinta salawat Habib Syekh). Kegiatan ini telah secara rutin digelar sejak berdirinya pada Juni 2008 dengan satu atau lebih munsyid (pelantun salawat), dan diiringi dengan alat hadrah/ rebana oleh para personil grup Ahbaabul Musthofa Yogyakarta. Penyelenggaraan rutinan majelis Ahbaabul Musthofa di kabupaten Sleman merupakan satu media yang berperan penting dalam rangka da'wah islamiyyah kepada umat. Melalui simbol-simbol yang ada pada kegiatan tersebut, khususnya seni hadrah, para pegiat majelis Ahbaabul Musthofa ingin menyampaikan pesan dakwahnya pada masyarakat luas.

Uraian di atas sekaligus mengarahkan pembaca akan tujuan dari penelitian ini, yaitu untuk menyingkap makna yang terdapat pada simbol-simbol seni hadrah majelis Ahbaabul Musthofa Yogyakarta, sehingga harapannya mad'u dapat mengambil hikmah darinya serta dapat mengaplikasikannya ke dalam kehidupan mad'u, khususnya bagi jamaah Syekher Mania Yogyakarta. Sebagai data pendukung, grup hadrah Abaabul Musthofa merupakan grup yang istimewa karena dikenal oleh masyarakat luas sebagai grup yang dipercaya untuk mengiringi salawat Syekh Abdul Qodir Assegaf/ Habib Syekh, sehingga memiliki track record yang cukup bagus. Selain itu grup ini juga menjadi rujukan bagi sebagian besar grup hadrah di Yogyakarta (Hendi Susanto, 2018).

\section{Kajian Pustaka}

\section{Teori Interaksi Simbolik}

Untuk mengantarkan pada permasalahan, dalam penelitian ini peneliti mencantumkan teori interaksi simbolik. Teori interaksi simbolik dikembangkan 
oleh kelompok The Chicago School dengan tokoh-tokohnya seperti George Herbert Blumer dan George Herbert Mead. Menurutnya, peneliti perlu mencoba berempati dengan pokok materi, masuk dalm pengalamannya, dan usaha untuk memahami nilai dari tiap orang. Dalam memahami interaksi simbolik, Blumer dan Mead memiliki pandangan yang sedikit berbeda (Muhammad Mufid, 2009: 147). Blumer berpandangan bahwa;

a. Manusia berperilaku terhadap hal-hal berdasarkan makna yang dimiliki hal-hal tersebut baginya.

b. Makna hal-hal tersebut berasal dari atau muncul dari interaksi sosial yang pernah dilakukan dengan orang lain.

c. Makna-makna itu dikelola dalam dan diubah melalui proses penafsiran yang dipergunakan oleh orang yang berkaitan dengan hal-hal yang dijumpai.

Adapun menurut Mead, interaksi simbolik berpedoman pada enam hal, yakni (Morissan, 2002:143);

a. Manusia membuat keputusan dan bertindak pada situasi yang dihadapinya sesuai dengan pengertian subjektifnya

b. Kehidupan sosial merupakan proses interaksi, kehidupan sosial bukanlah struktur atau bersifat struktural dan karena itu ia dinamis.

c. Manusia memahami pengalamannya melalui makna dari simbol yang digunakan di lingkungan terdekatnya (primary group), dan bahasa merupakan bagian yang sangat penting dalam kehidupan sosial.

d. Dunia terdiri atas berbagai objek sosial yang memiliki nama dan makna yang ditentukan secara sosial

e. Manusia mendasarkan tindakannya atas interpretasi mereka, dengan mempertimbangkan dan mendefinisikan objek-objek dan tindakan yang relevan pada situasi saat itu.

f. Diri seseorang adalah objek signifikan dan sebagaimana objek sosial lainnya diri didefinisikan melalui interaksi sosial dengan orang lain.

Dari keenam gagasan di atas, setidaknya terdapat tiga konsep penting dan utama yang dikemukakan oleh Mead, yakni masyarakat, diri, dan pikiran. Ketiga konsep tersebut memang merupakan aspek yang berbeda, namun berasal dari proses yang sama, yaitu "tindakan sosial". Tindakan dimulai dari dorongan hati 
yang melibatkan persepsi dan pemberian makna, latihan mental, pertimbangan alternatif, dan penyelesaian (Morissan, 2002: 143-144).

Dalam komunikasi, ada bagian penting yang perlu kita ketahui, yakni makna. Makna dapat diperoleh dari hasil interaksi dengan orang lain, kemudian digunakan untuk menginterpretasikan peristiwa di sekitar kita. Proses internal di dalam diri kita menuntut kita untuk memilih, memeriksa, menyimpan, mengelompokkan, dan mengirim makna sesuai dengan situasi di mana kita berada dan arah tindakan kita. Maka, kita tidak dapat berkomunikasi dengan orang lain jika kita tidak memiliki kesamaan makna terhadap simbol yang digunakan dengan lawan bicara kita (Morissan, 2002: 145).

\section{Analisis Etnografi Spradley}

Pada penelitian ini peneliti mencoba menganalisis permasalahan menggunakan analisis etnografi Spradley. Menurut Spradley, ada beberapa tahapan yang perlu ditempuh peneliti untuk meneliti permasalahan etnografi, yaitu (Emzir, 2010:165);

(1) Analisis Domain, yaitu memperoleh gambaran umum dan menyeluruh dari objek penelitian atau situasi sosial. Hal ini didapatkan melalui observasi dan wawancara kepada partisipan. Melalui pertanyaan umum dan rinci, peneliti menemukan berbagai kategori atau domain tertentu sebagai acuan penelitian selanjutnya.

(2) Analisis Taksonomi, yaitu menjabarkan domain-domain yang dipilih menjadi lebih rinci untuk mengetahui struktur internalnya. Hal ini dilakukan melalui pengamatan yang lebih terfokus.

(3) Analisis Komponensional, yaitu mencari ciri spesifik pada struktur internal dengan cara mengontraskan antar elemen. Langkah ini dapat dilakukan melalui observasi dan wawancara yang lebih selektif melalui pertanyaan yang mengontraskan.

(4) Analisis Tema Budaya, yakni mencari hubungan di antara domain dan hubungan dengan keseluruhan. Kemudian dinyatakan ke dalam tematema budaya sesuai dengan fokus penelitian. 


\section{Seni Hadrah Ahbaabul Musthofa sebagai Media Komunikasi}

Prof. Dr. Sutrisno, M.Ag. menggolongkan seni ke dalam beberapa macam, yakni seni rupa, seni musik, seni tari, seni sastra dan seni drama (Sutrisno, 2016:21). Sebagai bagian dari seni, musik sebetulnya dekat sekali dengan kehidupan sehari-hari umat Muslim, bahkan dalam hal peribadatan sekalipun. Dikatakan seperti itu, karena secara tidak sadar konsep musik sudah biasa kita terapkan dalam kehidupan kita, yakni seperti saat kita melantunkan ayat alquran, mengumandangkan seruan adzan, melantunkan salawat dan juga nyanyian religi sebagai upaya untuk mengingat Allah SWT. dan Rasul-Nya.

Sama halnya dengan seni hadrah, seni hadrah termasuk dalam jenis kegiatan seni musik klasik yang dilakukan untuk mendekatkan diri kepada Allah SWT dengan cara melantunkan salawat atas Nabi Muhammad SAW dan diiringi alat bernama rebana. Hadrah sendiri berasal dari bahasa Arab, yakni hadhoroyahdhiru-hadhron-hadhrotan yang berarti kehadiran. Namun kebanyakan istilah hadrah diartikan sebagai irama yang dihasilkan oleh bunyi rebana (sejenis alat kesenian tradisional yang terbuat dari kayu, berbentuk lingkaran dan terdapat lubang di tengahnya, kemudian pada lubang tersebut ditempeli kulit binatang (biasanya kulit kambing) yang telah dibersihkan bulu-bulunya. Pukulan tangan pada kulit tersebut dapat menimbulkan bunyi yang enak didengar) (Abdul Mun'im, 2015:15).

Sebetulnya, kegiatan seni hadrah sudah lama ada sejak zaman kenabian Rasulullah SAW. Dikisahkan, setibanya Rasulullah SAW. di kota Madinah untuk berhijrah, beliau disambut meriah oleh masyarakat kaum Anshar dengan melantunkan salawat Tala'al badru, dan diiringi tabuhan rebana. Adapun di Indonesia sendiri, hadrah biasa digunakan sebagai instrumen untuk mengiringi bacaan salawat, syair-syair Arab, dan sebagainya. Oleh karena kegunaannya yang demikian, maka seni hadrah di beberapa kalangan juga populer dengan istilah rebana (rebana berasal dari kata rabbana, yang berarti "Wahai Tuhan kami", yakni suatu doa dan pujian kepada Tuhan) (Seyyed Hossein Nasr: 2003).

Pada praktinya, seni hadrah biasa ditampilkan dalam berbagai acara, baik formal maupun nonformal, contohnya perayaan maulid Nabi SAW, Isra' Mi'raj, peresmian perkawinan, sunatan, peringatan hari besar Islam, dan acara-acara sakral lainnya. Adapun kegiatan yang paling sering menghadirkan seni hadrah 
adalah event maulid Nabi, atau rutinan maulidan yang biasa diselenggarakan sepekan sekali atau selapan sekali. Seni hadrah setidaknya melibatkan empat orang untuk menabuh rebana. Munsyid (pelantun salawat) melantunkan kasidah/ salawat di sela-sela pembacaan fashal (sebutan "bab" di dalam kitab), kemudian biasanya hadirin secara otomatis akan mengikuti syair yang dilantunkan oleh munsyid (Abdul Mun'im, 2015:16). Beberapa kitab maulid yang populer di kalangan muslim Indonesia adalah kitab maulid al-barzanji, syarof alanam, al-diba', simt ad-durar, kasidah burdah, dan ratib al-haddad.

Membaca salawat atas Nabi Muhammad SAW tentu memiliki keutamaan. Di antaranya yakni memenuhi sebagian hak Rasulullah SAW sebab beliau adalah perantara antara Allah dengan hamba-Nya, memenuhi perintah Allah, memohon syafaat di hari akhir kelak, mendapatkan surga yang bertambah luasnya, kemudahan segala urusan baik di dunia maupun di akhirat, dan memohon keberkatan (Mahmud Samiy, 1992: 9). Hal ini tentu diperuntukkan kepada mereka yang benar-benar ikhlas melakukannya dan melaksanakan hak-haknya, dan disertai rasa penghormatan dan cinta kepada beliau.

Perkembangan seni hadrah di Indonesia tampaknya hingga hari ini semakin menunjukkan peningkatan dari segi kuantitas. Hal ini terlihat dari menjamurnya berbagai majelis maulid, dzikir dan salawat di berbagai daerah dan diperankan oleh banyak elemen masyarakat. Bahkan di DIY, seni hadrah dewasa ini marak diperlombakan, baik untuk anak-anak, remaja, bapak-bapak, maupun ibu-ibu. Seni hadrah di satu sisi memang merupakan media hiburan karena lantunan syair dan iramanya yang indah dan menyentuh, akan tetapi banyak orang tidak menyadari sebetulnya seni hadrah merupakan suatu media komunikasi dakwah, di mana pesan-pesannya tercermin pada simbol-simbol yang ada.

Untuk mengetahui seberapa jauh pemahaman jamaah majelis Ahbaabul Musthofa tentang simbol-simbol dan pesan yang terdapat pada seni hadrah Ahbaabul Musthofa, peneliti melakukan wawancara kepada beberapa jamaah yang tergabung dalam komunitas Syekher Mania. Meski memiliki latar belakang pendidikan yang berbeda-beda (santri dan non santri), namun komunitas ini memiliki budaya yang khas dan menjadi identitas mereka. Budaya yang dimaksud yaitu paseduluran dan kebersamaan antar anggota. Seringnya melakukan kumpul-kumpul, berangkat berbondong-bondong dari satu majelis ke majelis 
lain dan selalu meramaikan majelis salawat membuat para anggota menjalin paseduluran dan merasakan kebersamaan satu sama lain. Peneliti pun melakukan wawancara kepada sebagian anggota. Hasilnya, banyak dari jamaah Syekher Mania ternyata belum memahami apa pesan yang ingin disampaikan melalui seni hadrah tersebut. Mereka hanya tertarik dan merasa nyaman ketika mengikuti kegiatan yang berbasis hadrah dan salawat.

Lalu apa saja simbol yang digunakan dalam seni hadrah Ahbaabul Musthofa? Peirce menggolongkan tanda ke dalam tiga kategori, yakni ikon, indeks, dan simbol. Jika tanda menyerupai yang dilambangkan seperti foto, lukisan, atau sejenisnya, maka disebut ikon. Apabila tanda menunjukkan adanya sesuatu seperti timbulnya asap karena ada api, maka disebut indeks. Jika tanda tidak menyerupai yang dilambangkan, seperti burung garuda melambangkan negara Republik Indonesia, maka disebut dengan simbol atau lambang (Abdul Latif Abu Bakar, 2006). Untuk mengetahui apa saja simbol yang digunakan dalam seni hadrah Ahbaabul Musthofa, maka peneliti melakukan observasi lapangan sebanyak empat kali di masjid Jenderal Sudirman Yogyakarta (sempat berpindah tempat di Laboratorium Agama Sunan Kalijaga Yogyakarta dan kini berlokasi di Dusun Tajem Maguwoharjo Sleman), dan melakukan wawancara kepada pihakpihak terkait

\section{Metode}

Penelitian ini menggunakan jenis penelitian lapangan dengan data kualitatif. Dalam melakukan penelitian, peneliti menggunakan pendekatan etnografi, yakni penelitian yang berupaya untuk memperhatikan makna-makna tindakan dari kejadian yang menimpa orang yang ingin kita pahami. Makna-makna tersebut diekspresikan baik secara langsung melalui bahasa maupun tidak langsung yakni melalui perbuatan (James P. Spradley, 2006:5).

Subjek dalam penelitian ini adalah ketua penyelenggara majelis Ahbaabul Musthofa Yogyakarta, ketua grup hadrah Ahbaabul Musthofa, ketua komunitas Syekher Mania, jamaah Syekher Mania Sleman Yogyakarta, dan para ahli bidang hadrah serta seni musik di Yogyakarta. Adapun objek penelitiannya berfokus pada simbol-simbol yang terdapat pada seni hadrah majelis Ahbaabul Musthofa. 
Dalam proses pengumpulan data, peneliti terlebih dahulu membagi sumber data menjadi dua jenis, yaitu sumber data primer dan data sekunder. Sumber data primer didapatkan dari subjek penelitian dengan cara melakukan pengamatan, percobaan, dan wawancara. James P. Spradley menyatakan bahwa, teknik pengumpulan data utama pada penelitian etnografi adalah melalui observasipartisipasi dan wawancara terbuka dan mendalam yang dilakukan dalam jangka waktu yang relatif ( ames P. Spradley, 2006:5).

Adapun sumber data primer pada penelitian ini adalah observasi lapangan, wawancara mendalam, dan studi pustaka. Dalam penelitian ini, observasi dilakukan secara partisipatif, yakni peneliti menjadi pengamat langsung ketika kegiatan seni hadrah majelis Ahbaabul Musthofa berlangsung. Peneliti mengikuti kegiatan rutinan Majelis Ahbaabul Musthofa Yogyakarta dari awal hingga akhir acara, yakni ikut bersalawat, berdzikir, mendengarkan ceramah, dan lain-lain. Ikut terlibat dalam observasi partisipatif memudahkan peneliti untuk menempuh tahap pencarian data berikutnya, yaitu wawancara mendalam.

Pada tahap wawancara mendalam, peneliti melakukan wawancara kepada beberapa pihak yang menjadi subjek penelitian, yang telah dijelaskan di muka. Adapun penelitian melalui studi pustaka, peneliti memanfaatkan literatur berupa buku, skripsi, dan artikel jurnal penelitian untuk mengumpulkan data tentang makna simbol dalam komunikasi seni hadrah.

Sumber data yang kedua adalah sumber data sekunder. Sumber data sekunder adalah data yang tidak langsung diperoleh dari sumber pertama dan telah tersusun dalam bentuk dokumen tertulis. Sumber tersebut didapatkan oleh peneliti melalui dua cara, yaitu dokumentasi foto kegiatan majelis Ahbaabul Musthofa dan penelitian terdahulu yang berkaitan dengan tema peneliti sebagai tambahan keterangan data serta pembanding.

\section{Hasil Penelitian dan Pembahasan}

\section{Simbol pada Seni Hadrah Majelis Ahbaabul Musthofa dan Maknanya}

Setelah melakukan observasi lapangan di masjid Jenderal Sudirman Yogyakarta dan wawancara kepada pihak-pihak terkait, peneliti menemukan empat unsur yang menjadi simbol pada seni hadrah majelis Ahbaabul Musthofa 
Yogyakarta. Simbol ini meliputi vokal, instrumen, gerakan, dan busana. Keempat simbol ini merupakan unsur-unsur yang paling menonjol pada pementasan seni hadrah Ahbaabul Musthofa dan menjadi ciri khas yang membedakannya dengan majelis-majelis lain.

Vokal dalam seni hadrah diperankan olah pelantun salawat atau biasa disebut munsyid. Intonasi lagu bisa bermacam-macam, akan tetapi biasanya seorang munsyid membawakan lagu dengan nada tinggi dan menggebu. Hal ini karena munsyid merupakan media penyampai syair berisi kabar gembira bagi umat.

Instrumen menyatukan keragaman dan musik tradisional Islam, kemudian memunculkan kesadaran manusia melalui jalan keindahan (Seyyed Hossein Nasr, 2003:640). Instrumen dimainkan untuk menghasilkan irama dan meloldi. Dalam musik, terdapat penafsiran tentang dua aspek mengenai Allah. Pertama, aspek keagungan (al-jalal) yang berarti irama. Kedua, aspek keindahan (al-jamal) yang berarti melodi (Seyyed Hossein Nasr, 2003:640). Irama merupakan pola ritme tertentu dalam melagukan syair, sedangkan tingkatan nada/ mode/ maqam, merupakan salah satu tipe melodi yang diekspresikan melalui serangkaian suara yang disusun dengan baik. Adapun instrumen yang digunakan dalam pementasan seni hadrah pada umumnya tidak hanya rebana, akan tetapi kolaborasi antara rebana dengan dumbuk, bass, tam, kaplak dan icik-icik, dan memiliki fungsi dan makna tertentu.

Dalam kesenian hadrah melibatkan gerakan tubuh, baik pada penabuh rebana maupun munsyid. Seyyed Hossein Nasr menyatakan bahwa dasar dari hadrah ialah kata-kata Nabi yang ditujukan kepada para sahabat tertentu yang melahirkan ekspresi-ekspresi fisik karena kegembiraan yang menggelora, lalu ditiru oleh sahabatnya yang lain, dan diulangi pada generasi berikutnya (Seyyed Hossein Nasr, 2003:623), sehingga dapat ditarik kesimpulan bahwa gerak tubuh yang diekspresikan merupakan simbol kegembiraan dan kekhusyukan bagi para pelaku seni hadrah.

Busana yang dikenakan oleh para pemain seni hadrah umumnya adalah busana muslim. Adapun dalam kegiatan salawat, kita disunahkan untuk memakai pakaian berwarna putih. Diriwayatkan oleh Imam Ahmad, Abu Daud, Turmudzi, Nasai dan Ibnu Majah, serta dinyatakan sahih oleh Hakim bahwa Rasulullah SAW 
bersabda,

"Carilah oleh kamu pakaian putih, lalu pakailah karena ia merupakan pakaian terbaik dan paling bersih, serta kafanilah dengannya mayat-mayat kamu!". (Majelis Tertinggi Urusan Keislaman Mesir, Sunnah-sunnah Pilihan, 2007:323)

Dari hadits tersebut jelaslah bahwa mengenakan pakaian berwarna putih merupakan sebuah keutamaan. Warna putih melambangkan kesucian, sehingga diharapkan tidak hanya tampilan fisik saja yang suci, akan tetapi jiwa yang merindukan Rasulullah SAW pun suci.

Setelah peneliti mendapatkan data tentang simbol yang digunakan pada seni hadrah majelis Ahbaabul Musthofa, peneliti mencoba menganalisis simbolsimbol tersebut menggunakan analisis etnografi Spradley. Ada empat tahapan analisis yang harus dilalui dalam analisis etnografi Spradley, yaitu meliputi analisis domain, analisis taksonomi, analisis komponensional, dan analisis tema budaya. Berawal dari empat tahapan analisis ini, akhirnya peneliti memperoleh informasi tentang makna-makna dari setiap simbol yang ada. Adapun penjabaran tahapan analisis beserta hasil penelitiannya adalah sebagai berikut;

\section{(1) Analisis Domain}

Pada tahapan ini, peneliti mendapatkan gambaran umum dari keempat simbol pada seni hadrah majelis Ahbaabul Musthofa Yogyakarta. Perlu diketahui bahwa data yang diperoleh pada tahapan ini adalah berupa informasi yang masih umum mengenai vokal, instrumen, gerakan dan busana pada seni hadrah majelis Ahbaabul Musthofa, belum masuk pada makna secara rinci. Adapun hasil dari tahapan analisis domain adalah;

a. Jenis vokal pada seni hadrah Ahbaabul Musthofa Yogyakarta adalah vokal yang mengutamakan penghayatan dan rasa nikmat ketika bersalawat.

b. Instrumen yang digunakan pada seni hadrah Ahbaabul Musthofa Yogyakarta adalah alat-alat banjari klasik berupa rebana, kaplak, bass, dan darbuka. Keempat instrumen ini menjadi ciri khas pada Ahbaabul Musthofa, karena pada kelompok kesenian hadrah lainnya ada pula yang menggunakan alat elektrik sebagai tambahan.

c. Gerakan yang ditampakkan secara menonjol adalah gerakan melempar rebana ke udara, kemudian menangkapnya, dan gerakan berdiri dan menengadahkan tangan saat tiba sesi mạ̣al al-qiyām. 
Kedua gerakan ini merupakan ciri khas dari seni hadrah majelis Ahbaabul Musthofa Yogyakarta.

d. Busana yang dikenakan pada majelis Ahbaabul Musthofa Yogyakarta secara dominan adalah pakaian takwa berwarna putih, bersarung dan berkopyah.

\section{(2) Analisis Taksonomi}

Analisis Taksonomi merupakan penjabaran domain-domain yang dipilih menjadi lebih rinci untuk mengetahui struktur internalnya. Hal ini dilakukan melalui pengamatan yang lebih terfokus dan wawancara lebih mendalam kepada informan yang terpercaya. Adapun hasil dari tahapan analisis taksonomi yang dilakukan oleh peneliti adalah sebagai berikut;

a. Vokal

Arranger sekaligus composser, R Merlis Kustoyo, menyatakan bahwa vokal adalah suara manusia yang berperan dalam kegiatan musikal, dapat berupa paduan suara, solo vokal, akapela atau lainnya yang memerankan instrumen (R. Merlis Kustoyo, 2018). Vokal pada seni hadrah Ahbaabul Musthofa berperan dalam menyanyikan lagu kasidah atau salawat, membaca ratib al-ḥadad, dan membaca kitab maulid șimt ad-durar. Adapun jenis vokal pada seni hadrah majelis Ahbaabul Musthofa Yogyakarta tidak memiliki patokan khusus dan tidak ada keharusan memiliki vokal dengan jenis tertentu. Namun, ada satu hal yang menjadi prinsip bagi seorang munsyid pada seni hadrah majelis Ahbaabul Musthofa, yakni harus dapat membangun rasa nikmat ketika bersalawat (Hendi Susanto, 2018).

Untuk membangun rasa nikmat, tentu munsyid harus bernyanyi dengan penuh penghayatan. Jika seorang munsyid sudah merasakan nikmatnya bersalawat, maka ia akan membawakan lagu kasidahnya dengan rasa yang dalam dan kenikmatan tersebut juga dirasakan oleh para jamaah. Seseorang dapat dikatakan sebagai munsyid sejati apabila memenuhi empat kriteria menjadi munsyid, yakni ḥusnut-tażawwuq (bagusnya penghayatan), husnul qiraah (bagusnya pembacaan), ma'rifatul qasidah (mengetahui apa yang dibaca), dan h usnul adab (adab atau sopan santun) (Sholeh Ilham, 2018). 
Adapun pada seni hadrah Ahbaabul Musthofa, kriteria yang paling ditekankan dan diutamakan adalah husnuttażawwuq, yakni seorang munsyid harus dapat menghadirkan rasa nikmat dan penghayatan ketika melantunkan salawat Nabi. Hal ini menjadi prinsip yang paling utama bagi para munsyid saat melantunkan salawat pada kegiatan rutinan majelis Ahbaabul Musthofa Yogyakarta.

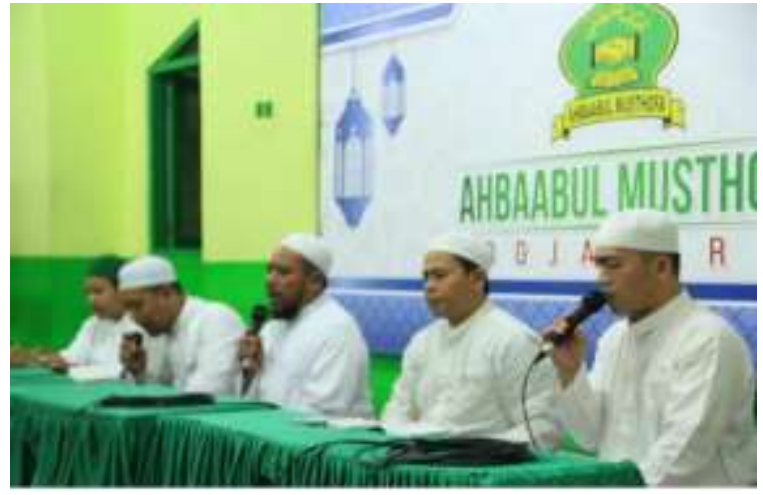

Gambar 1. Para munsyid grup hadrah majelis Ahbaabul Musthofa

b. Instrumen

Instrumen merupakan unsur yang sangat vital bagi sebuah pertunjukan musik, termasuk seni hadrah. Instrumen yang digunakan pada seni hadrah majelis Ahbaabul Musthofa adalah alat-alat klasik model al-Banjari yang meliputi rebana, bass, kaplak dan darbuka.

Rebana adalah jenis instrumen musik membranofon, yaitu instrumen yang bunyi suaranya dihasilkan oleh membran atau kulit. Bentuk bulatannya berasal dari kayu yang berlubang di tengahnya. Lubang pada kayu ditutup dengan kulit yang telah disamak. Kulit inilah yang kemudian mengeluarkan suara ketika dipukul. Pada setiap rebana juga ditemukan tiga lempengan logam tipis di tepi. Pukulan ini juga diharuskan mengeluarkan suara tak (T) dan dik (D) yang keras (Abdul Najib, 2017:75). Dalam memainkan rebana terdapat dua jenis pukulan, yakni gerinci dan tikah. Untuk memainkan kedua pukulan tersebut perlu dilakukan secara berpasangan. Idealnya, rebana dimainkan oleh 4 orang pemain, meliputi dua pemain tikah dan dua pemain gerinci. Adapun rumus pukulan untuk gerinci adalah D TT DDD T TD, dan Tikah adalah DT TDD TD (Tulus Tri Nugroho, 2018). 


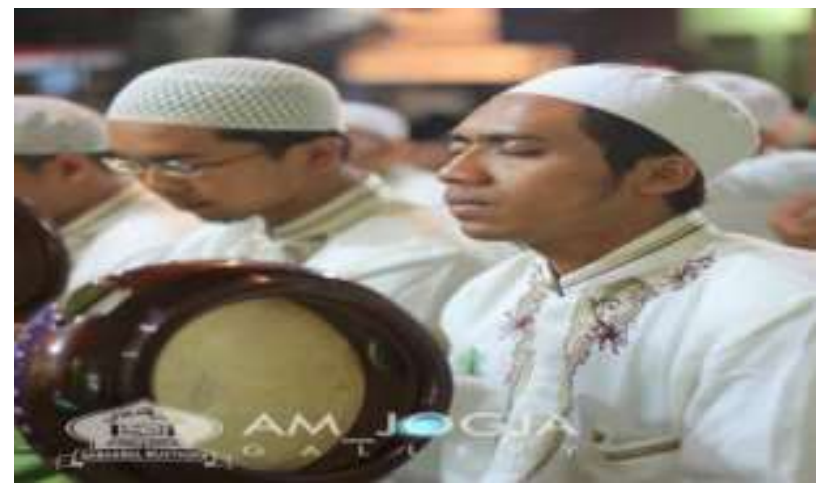

Gambar 2. Rebana

Bass adalah alat pendukung dalam sebuah pementasan seni hadrah. Bass memiliki jenis yang bermacam-macam sesuai dengan ukurannya. Adapun bass yang digunakan pada seni hadrah Majelis Ahbaabul Musthofa Yogyakarta adalah bass pukul dengan ukuran besar. Cara memainkannya adalah dengan dipukul menggunakan alat pemukul (stick), dan menimbulkan bunyi dug dug. Fungsi bass pada seni hadrah adalah sebagai pengatur tempo dan ritmis (Ahmad Aslamul Faizin, 2018). Rumus pada bass pukul dilambangkan dengan huruf $D$, yakni sebagai berikut: D / DD D, D / DD D D, D / D D D

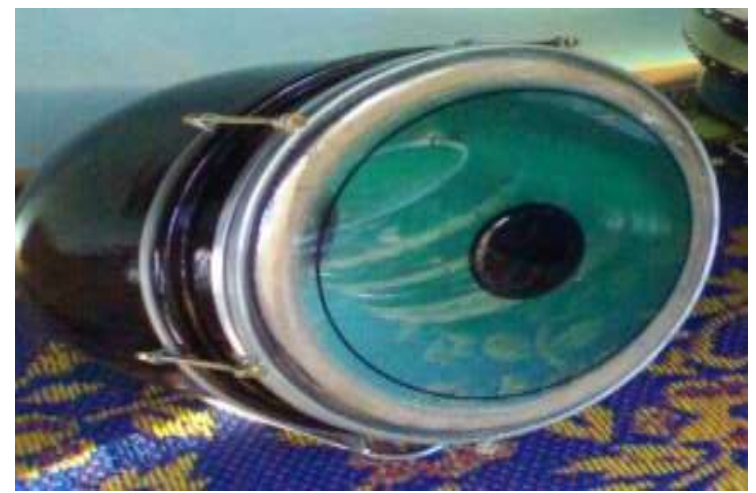

Gambar 3. Bass

Selanjutnya, Kaplak merupakan alat yang serupa dengan rebana, hanya saja memiliki ukuran yang lebih kecil dan tidak memiliki lempengan logam tipis. Kaplak dimainkan menggunakan tangan, sama seperti sedang bertepuk tangan, dan ketika dipukul akan berbunyi plak. Dalam pementasan seni hadrah, kaplak tidak dimainkan sesering rebana, ia hanya sebagai pemanis pada lagu kasidah, sehingga terasa 
lebih rancak dan semarak. Biasanya alat ini dimainkan ketika memasuki perpindahan lagu atau saat lagu memasuki bagian chorus. Pukulan pada kaplak digambarkan dengan simbol huruf T (tung) dan P (plak) (Tulus Tri Nugroho, 2018). Adapun rumus pukulan pada kaplak adalah: Pemain 1:TP T, Pemain 2: TP TP

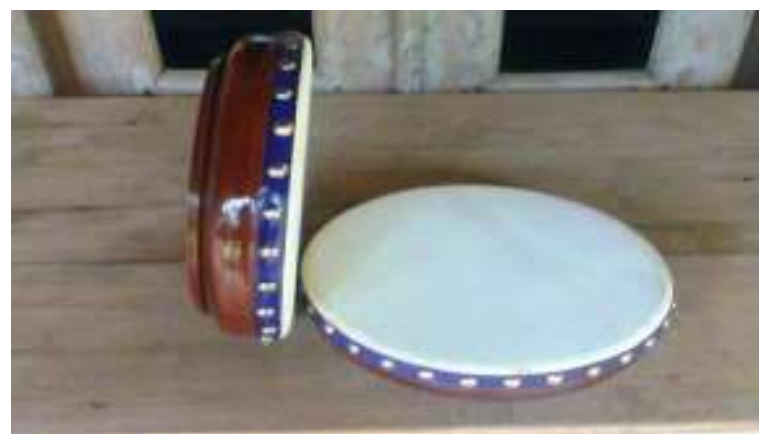

Gambar 4. Kaplak

Terakhir, Darbuka, berbentuk seperti dandang dan terbuat dari bahan alumunium. Alat ini merupakan alat yang banyak diminati kalangan anak muda. Darbuka yang digunakan pada seni hadrah majelis Ahbaabul Musthofa Yogyakarta adalah jenis darbuka ukuran standar, yakni $22 \mathrm{~cm}$. Darbuka dimainkan pada saat lagu memasuki reff dengan cara dipukul menggunakan jari, dan menimbulkan bunyi tek, dum, dan slap sebagai variasi. Adapun untuk Ahbaabul Musthofa sendiri menggunakan ritme D T T D T (Dum Tek Tek Dum Tek) (M. Fatah Asysyafi, 2018).

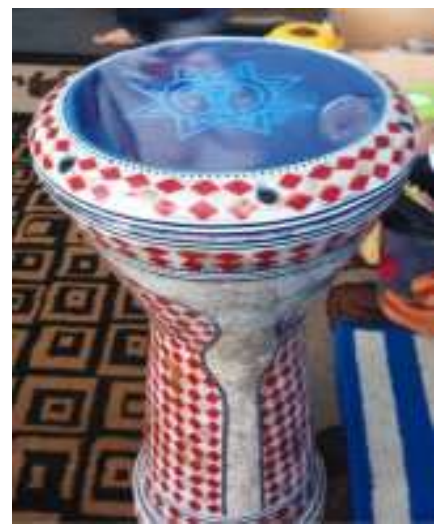

Gambar 5. Darbuka 


\section{c. Gerakan}

Gerakan dalam seni hadrah bukan menjadi suatu keharusan untuk dilakukan. Gerak merupakan ekspresi yang timbul akibat suasana irama lagu yang dilantunkan. Itulah yang menyebabkan timbulnya gerakan, baik bagi pelaku seni hadrah maupun jamaah. Hal ini tentu dengan catatan bahwa gerakan yang dilakukan masih dalam batas kewajaran dan tidak merugikan jamaah lain. Dalam seni hadrah majelis Ahbaabul Musthofa ini setidaknya ada dua jenis gerakan yang menonjol dan bermakna, yaitu:

(1) Gerakan melempar rebana ke atas dan menangkapnya. Hal ini dilakukan pada saat munsyid melantunkan lagu kasidah Ya Hanana. Di sini para pemain rebana harus memiliki kemampuan keseimbangan agar rebana dapat ditangkap dengan tepat sasaran.

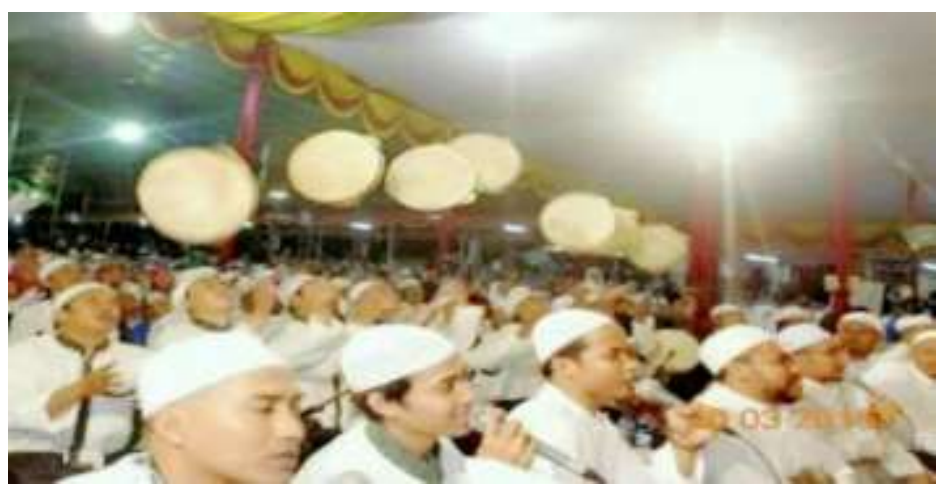

Gambar 6. Gerakan melempar rebana ke atas dan menangkapnya

(2) Gerakan berdiri dan menengadahkan tangan saat maḥal al-qiyām.

Gerakan ini dilakukan oleh seluruh hadirin pada bagian tertentu saat pembacaan kitab maulid. Bagian ini disebut dengan mahal alqiyām, yang artinya "saat untuk berdiri". Biasanya pada bagian ini para jamaah berdiri dan menengadahkan tangan layaknya orang yang sedang berdoa. Kekhusyukan jamaah pada saat mahal alqiyām tak jarang membuat mereka tersentuh sehingga meneteskan air matanya. 


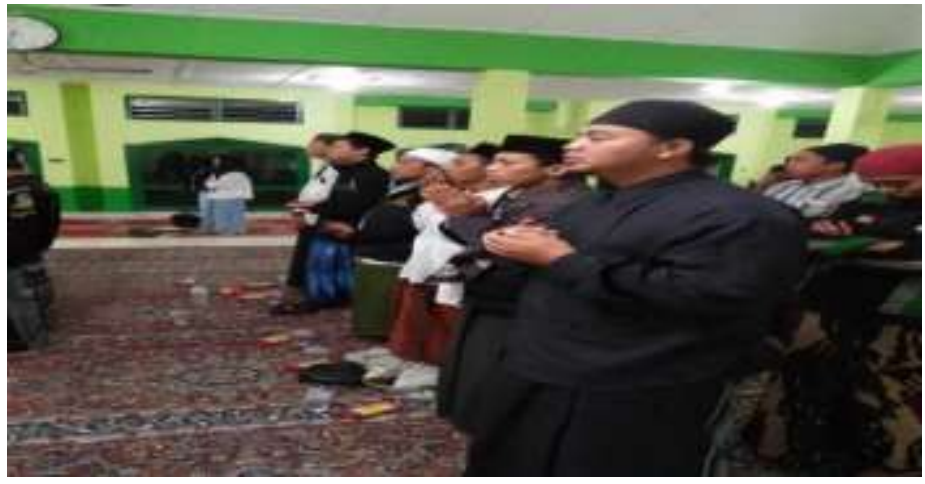

Gambar 7. Gerakan berdiri dan menengadahkan tangan saat maḥal al-qiyām

d. Busana

Busana yang dikenakan pada saat mengikuti majelis salawat boleh bermacam-macam. Tetapi dalam kegiatan seni hadrah majelis Ahbaabul Musthofa Yogyakarta, hal yang paling ditekankan adalah pakaian harus tetap menutup aurat dan tidak berlebihan, dengan kata lain masih dalam batas kewajaran. Adapun sunnah yang dianjurkan oleh panitia penyelenggara kegiatan majelis Ahbaabul Musthofa adalah baju takwa berwarna putih, memakai kain sarung dan berkopyah.

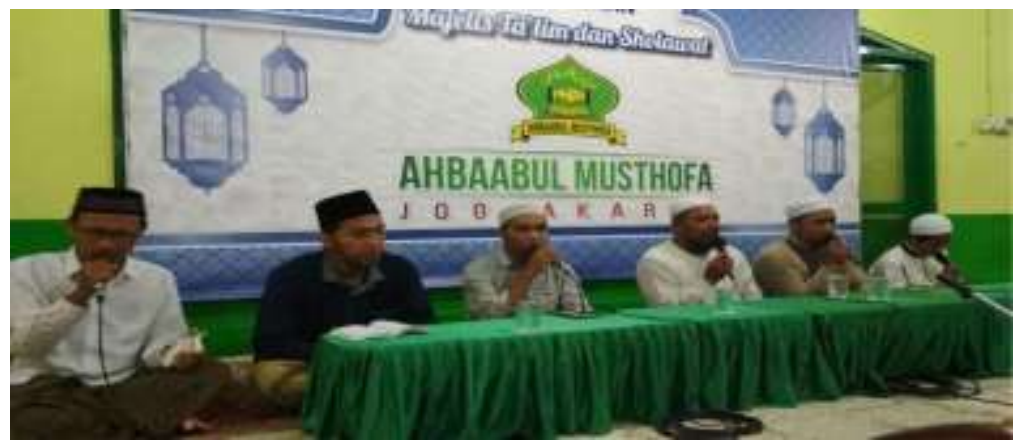

Gambar 8. Busana

\section{(3) Analisis Komponensional}

Pada analisis komponensional, hal yang pokok untuk diorganisasikan adalah perbedaan dalam domain atau kesenjangan yang kontras dalam domain. Dalam mencari informasi tentang suatu simbol, peneliti tidak berpatokan pada satu sumber saja, akan tetapi menggali data dari beberapa informan. Hasilnya menunjukkan beberapa perbedaan data yang didapatkan mengenai simbol pada seni hadrah majelis Ahbaabul Musthofa Yogyakarta. Sebagai contoh, pada bagian vokal, peneliti tidak hanya 
melakukan wawancara kepada vokalis hadrah, akan tetapi juga kepada ahli bidang musik, sehingga didapatkan data yang bervariasi.

Di samping itu, ketika peneliti merasa belum puas dengan hasil wawancara yang dilakukan kepada para informan, peneliti melakukan wawancara lanjutan kepada beberapa dari mereka, yakni melaui media sosial WhatsApp. Dari sini kemudian peneliti membandingkan dan mengkombinasikan data dari para informan.

\section{(4) Analisis Tema Budaya}

Pada tahapan analisis tema budaya, peneliti mencari hubungan antar domain dan hubungan dengan keseluruhan. Melalui tahapan ini, peneliti mendapatkan data tentang makna simbol pada tiap domain-domain dan bagaimana interaksi yang dibangun oleh para pelaku seni hadrah melalui simbol-simbol tersebut kepada jamaah Syekher Mania.

Pertama, makna vokal pada seni hadrah majelis Ahbaabul Musthofa Yogyakarta. Prinsip utama bagi seorang munsyid pada majelis Ahbaabul Musthofa Yogyakarta adalah menguasai penghayatan. Hal tersebut selaras dengan tujuan musik yang diungkapkan oleh R. Merlis Kustoyo yakni untuk membangun ekstase (rasa nikmat) yang dicapai dengan adanya estetika dan etika (R. Merlis Kustoyo, 2018).

“...kalau pas kenikmatan sudah dirasakan bener-bener masuk ke hati mereka para vokalis, kenikmatan dapet, menggebugebu dapet, semangatnya lebih dapet" (Hendi Susanto, 2018)

Ketika seorang munsyid dapat menghadirkan rasa nikmat dalam bersalawat, maka vokal yang muncul bisa beragam. Nada rendah disimbolkan sebagai penghantar bagi jamaah pada sebuah perkenalan pertama, nada tinggi menyimbolkan klimaks, dan nada menggebu-gebu menyimbolkan suatu ekspresi kegembiraan, yang mana ketiga nada tersebut merupakan simbolisasi emosi natural manusia (R. Merlis Kustoyo, 2018). Selain menghadirkan rasa nikmat dalam bersalawat (ḥusnuttażawwuq), seorang munsyid juga harus memahami karakter lagu yang ia bawakan (ma'rifatul qasidah). Hal ini dapat diamati dari lirik lagunya, apakah memiliki makna sedih atau gembira.

Dalam kacamata musikologi, istilah ma'rifatul qasidah disebut juga 
dengan "psikologi musik". Psikologi musik mengatur bagaimana seseorang dapat memahami karakter lagu, karakter lirik, nada dan kata, sehingga pembawaannya dapat sesuai. Ketika sebuah lagu memiliki karakter yang sedih, maka vokalis harus membawakannya dengan sedih pula. Sebaliknya, lagu berkarakter bahagia harus dilantunkan dengan semangat dan bahagia pula. Jadi, bagaimanapun karakter musiknya, seorang vokalis harus dapat mempelajari cara menyanyikan lagu dengan benar sesuai dengan karakter yang diinginkan oleh lagu tersebut.

Vokalis yang baik adalah ia yang dapat menyanyi dengan benar dan penuh penghayatan, sehingga orang yang mendengarnya akan terhanyut dalam lagu yang dilantunkan. Menurut hasil pengamatan peneliti, para vokalis (munsyid) kelompok hadrah Ahbaabul Musthofa mampu melantunkan salawat sesuai dengan karakter yang diinginkan oleh masingmasing lagu tersebut. Para munsyid juga sukses mengajak seluruh jamaah secara interaktif untuk ikut menyerukan salawat di dalam majelis. Meskipun, tidak dapat dipungkiri bahwa tidak semua jamaah memahami makna dari setiap salawat yang dibawakan, akan tetapi minimal jamaah secara sukarela bersedia menyerukan salawat atas Nabi Muhammad SAW.

Memang, seorang munsyid harus memahami betul karakter dan maksud dari lagu yang akan ia bawakan. Lagu Țalama Asyku Garami menggambarkan kerinduan kepada Nabi Muhammad SAW, oleh karenanya, munsyid harus membawakannya dengan penuh penghayatan dan menuangkan rasa rindu sedalam-dalamnya pada lagu tersebut. Lagu $Y a$ Hanana menggambarkan kesemangatan, puji-pujian, maka cara membawakannya adalah dengan menggebu-gebu. Dari sinilah pemahaman akan karakter lagu dan makna lagu menjadi hal yang sangat penting bagi seorang munsyid. Ketika munsyid telah menguasai teknik tersebut, maka pesan cinta kepada Nabi Muhammad SAW akan dengan mudah sampai kepada hati jamaah.

Tujuan adanya pertunjukan musik adalah untuk mencapai adanya ekstase atau rasa nikmat bagi audiens. Ekstase dapat dicapai apabila terdapat dua unsur, yakni etika dan estetika. Etika artinya seorang munsyid harus memiliki teknik yang benar dalam menyanyikan kasidah. Teknik yang 
dimaksud adalah teknik membaca atau melafalkan lirik lagunya, baik pada lagu berbahasa Arab, Indonesia maupun Jawa. Untuk melafalkan lagu berbahasa Arab, munsyid harus memiliki pengucapan yang fasih. Hal ini disebut dalam salah satu kriteria munsyid, yakni huunsul qiraah. Seorang munsyid harus fasih dan benar dalam membawakan lirik berbahasa Arab, karena jika terdapat kesalahan dalam pengucapan akan berakibat pada berubahnya makna dari lirik tersebut. Adapun estetika atau keindahan, muncul ketika membawakan lagu. Keindahan bisa berasal dari instrumen yang mengiringinya, atau dari vokal sendiri. Ketika lagu berkarakter gembira, instrumen harus menciptakan suasana semarak dan vokalis harus menyanyi dengan ekspresi gembira pula.

Berdasarkan uraian di atas, maka seni hadrah, sebagai salah satu kesenian musik Islami yang berisi puji-pujian kepada Nabi Muhammad SAW, memiliki vokal yang melambangkan kenikmatan, ketenangan jiwa, keimanan, ketakwaan, rasa cinta dan kerinduan kepada Rasulullah, dan itulah ekstase yang ingin dicapai pada seni hadrah majelis Ahbaabul Musthofa Yogyakarta.

Kedua, yakni makna instrumen pada seni hadrah majelis Ahbaabul Musthofa Yogyakarta. Selain sebagai instrumen kasidah, sekumpulan instrumen yang dimainkan sejatinya menyimbolkan suatu kegembiraan. Hal ini dilihat dari fungsi seni hadrah pada mulanya, yaitu sebagai ekspresi kegembiraan saat Rasulullah dan kaum Muhajirin disambut oleh kaum Anshar ketika sampai di kota Madinah (Sholeh Ilham, 2018). Selain sebagai simbol kegembiraan, kebulatan bentuk instrumen pada seni hadrah melambangkan kebulatan tekad dalam bertakwa kepada Allah SWT. Takwa merupakan modal yang sangat krusial bagi seorang muslim untuk menjalani kehidupan. Ketakwaan pada seorang muslim akan menuntunnya untuk menjadi orang yang bijak dan berpijak pada jalan yang benar. Adapun keanekaragaman instrumen melambangkan keanekaragaman budaya di dunia ini, sehingga ketika dimainkan bersama-sama akan berpadu menjadi sebuah kekuatan budaya yang mengangkat nilai-nilai keagamaan (Wahyu Wiyatni, 2013:113).

Ketika satu instrumen dimainkan bersamaan dengan instrumen lain, 
tentu akan menimbulkan sebuah kesinambungan. Semua instrument tersebut harus dimainkan seirama dan sesuai porsinya, tidak boleh ada satupun instrumen yang mendominasi. Hal ini juga berkaitan dengan sisi ta'abuddiyah, yaitu penghambaan diri kita kepada Allah SWT.

"Karena salawat itu, kan perintah, terlepas itu adalah ungkapan cinta kepada kangjeng Nabi, penghormatan kepada kangjeng Nabi, ketika bersalawat itu kan kita membaca, berdoa, beribadah kepada Allah SWT, ini merupakan simbol ta'abbud, yaitu kita menghamba kepada Allah ta'ala dengan kita membaca salawat. Jadi filosofinya adalah ngibadah yang asyik kepada Allah ta'ala." (Sholeh Ilham, 2018)

Dari uraian di atas, dapat disimpulkan makna seni hadrah ditinjau dari instrumennya selain merupakan bentuk kegembiraan atas hadirnya Nabi Muhammad SAW, juga menjadi simbol kekuatan budaya, simbol penghambaan melalui ibadah yang asyik, serta menggambarkan kebulatan tekad dalam bertakwa kepada Allah SWT. Di sini dapat kita tarik benang merah bahwa sejatinya instrumen dalam seni hadrah merupakan suatu simbol yang memiliki makna yang dalam, akan tetapi pada realisasinya masih banyak orang belum memahami maknanya, terutama jamaah Syekher Mania sendiri.

Ketiga, makna dua gerakan pada seni hadrah Majelis Ahbaabul Musthofa Yogyakarta. Di awal, peneliti telah menyebutkan bahwa gerakan yang dimaksud adalah gerakan melempar rebana lalu menangkapnya, dan gerakan berdiri dan menengadahkan tangan saat maḥal al-qiyām.

a. Gerakan melempar rebana lalu menangkapnya

Gerakan ini menjadi bagian dari pertunjukan yang cukup menyita perhatian jamaah. Di sela-sela lantunan salawat, jamaah akan dikejutkan dengan gerakan para penabuh yang melemparkan rebananya ke udara lalu menangkapnya kembali dengan penuh rasa percaya diri dan hati-hati. Hal ini tidak semata-mata merupakan sebuah atraksi, namun memiliki tujuan yaitu untuk menularkan semangat dari para penabuh kepada jamaah. Merupakan suatu hal yang wajar ketika kita mengikuti sebuah kajian di dalam majelis, ada kalanya muncul rasa jenuh. Oleh karena itu, dengan dibuatnya gerakan tersebut, makajamaah yang semula 
merasa jenuh tentu merasa segar kembali dan dapat mengikuti majelis salawat dengan lebih khidmat.

b. Gerakan berdiri dan menengadahkan tangan saat mahal al-qiyām

Mahal al-qiyām berisi doa-doa dan penghormatan kepada Nabi Muhammad SAW. Berdasarkan istihsan (suatu perkara yang dianggap baik oleh para ulama), posisi berdiri pada saat mahal alqiyām menggambarkan penghormatan kepada Nabi Muhammad SAW. Dikatakan bahwa pada sesi ini Nabi Muhammad SAW hadir di dalam majelis, oleh karena itu diperlukan kekhusyukan, ketenangan, dan kenyamanan saat menyambut kedatangan beliau. Maḥal al-qiyām biasanya diisi dengan bertawasul (memohon kepada Allah SWT dengan perantara nama seseorang, yang dalam hal ini adalah Nabi Muhammad SAW).

Menurut sebagian ulama sufi, sesi maḥal al-qiyām adalah saat di mana doa-doa dikabulkan. Oleh karena itu, para munsyid mengajak kepada jamaah untuk menengadahkan tangan seraya memanjatkan doa dengan khusyu. Tidak lupa para munsyid mengingatkan para jamaah untuk melakukan tawasul terlebih dahulu kepada Nabi Muhammad SAW sebagai bentuk penghormatan. Pada sesi ini, tak jarang para jamaah meneteskan air matanya karena merasakan khidmatnya suasana dan rindu yang teramat dalam kepada Nabi Muhammad SAW. (Sholeh Ilham, 2018)

Keempat, makna busana pada seni hadrah Majelis Ahbaabul Musthofa Yogyakarta. Mengenakan pakaian berwarna putih adalah sunah yang dianjurkan oleh Nabi Muhammad SAW. Oleh karena itu, panitia penyelenggara menghimbau kepada seluruh jamaah yang hadir untuk mengenakan pakaian berwarna putih. Selain merupakan sunah rasul, warna putih juga merupakan simbol kesucian, keikhlasan, dan kejujuran (Sholeh Ilham, 2018). Suci yang dimaksud adalah suci secara lahir dan batin ketika bertemu dengan Rasulullah, ikhlas dalam memanjatkan doa dan salawat kepadanya, dan memiliki kejujuran terhadap segala hal. Adapun kain sarung dan kopyah melambangkan kesederhanaan seorang hamba. Pemakaian kain sarung merujuk pada kebiasaan yang dilakukan oleh seorang santri 
yang memiliki sikap sopan, santun, sederhana dan takzim kepada guru atau ulama (Hendi Susanto, 2018).

Demikian pembahasan mengenai simbol-simbol yang terdapat pada seni hadrah majelis Ahbaabul Musthofa Yogyakarta beserta maknanya. Komunikasi yang terjadi pada majelis tersebut adalah bagian dari sebuah proses interaksi antara komunikator (pelaku seni hadrah) dan komunikan (Jamaah, Syekher Mania) yang dilakukan melalui serangkaian simbol-simbol. Simbol tersebut menjadi media pertukaran pesan yang kemudian diberi makna oleh keduanya. Para pelaku seni hadrah berperan dalam menyampaikan pesan berupa ajaran Islam, khususnya kepada Syekher Mania, melalui empat simbol yang ditampakkannya, sedangkan Syekher Mania berperan sebagai penerima dan penafsir pesan. Simbol ini, meski tidak semua jamaah mengerti, namun lambat laun dapat diterima dan dipahami oleh Syekher Mania setelah melalui proses interaksi dan komunikasi yang dilakukan secara terus-menerus di dalam majelis Ahbaabul Musthofa.

Berdasarkan wawancara lanjutan yang dilakukan oleh peneliti kepada beberapa jamaah Syekher Mania, peneliti menemukan bahwa, simbol pada seni hadrah majelis Ahbaabul Musthofa dan pengalaman yang mereka dapatkan dari hasil interaksi antara pelaku hadrah dengan jamaah di dalam majelis, membuat mereka lebih memahami dan menghayati secara lebih dalam makna simbolik seni hadrah, yang mana tidak sekedar menjadi hiburan dan bentuk kecintaan akan Nabi Muhammad SAW semata. Beberapa di antara mereka kini memiliki pandangan atau pedoman dalam berperilaku yang berakar dari pemahaman terhadap simbol pada seni hadrah majelis Ahbaabul Musthofa. Dengan berbekal tradisi yang sudah kuat yaitu paseduluran dan kumpul-kumpul, dan ditambah dengan pemaknaan simbol pada seni hadrah majelis Ahbaabul Musthofa, maka Syekher Mania tidak hanya berperan sebagai penikmat salawat, akan tetapi memiliki pedoman yang kuat dalam berperilaku sesuai dengan tuntunan Nabi Muhammad SAW. Artinya, dengan adanya seni hadrah majelis Ahbaabul Musthofa tidak hanya menciptakan ruang silaturahmi antar sesama umat mulsim, namun juga memberikan pengaruh yang besar bagi kehidupan jamaah, khususnya Syekher Mania, baik kehidupan beragama, sosial, maupun budaya. 


\section{Simpulan}

Menurut hasil penelitian yang telah dipaparkan, seni hadrah rutinan majelis Ahbaabul Musthofa Yogyakarta memiliki empat macam simbol, yakni vokal, instrumen, gerakan, dan busana. Vokal melambangkan emosi natural manusia dalam membangun rasa nikmat dalam beribadah kepada Allah SWT., ketenangan jiwa, keimanan, ketakwaan dan rasa cinta kepada Nabi Muhammad SAW. Instrumen jika dilihat dari kegunaannya, melambangkan suasana kegembiraan. Kebulatan bentuk instrumen melambangkan kebulatan tekad dalam bertakwa kepada Allah SWT., keanekaragaman instrumen menggambarkan adanya toleransi keberagaman manusia di dunia, dan sebagai simbol penghambaan diri kepada Allah SWT. melalui ibadah yang asyik.

Adapun gerakan melempar rebana ke atas lalu menangkapnya merupakan simbolisasi dari rasa semangat untuk menjalani kehidupan, dan gerakan berdiri dan menengadahkan tangan pada saat mahal al-qiyām menyimbolkan sikap penghormatan terhadap hadirnya Nabi Muhammad SAW di dalam majelis salawat. Sesi mahal al-qiyām dipercaya sebagai saat terkabulnya segala hajat, maka dari itu gerakan menengadahkan tangan juga merupakan simbol pengungkapan doa seorang hamba kepada Tuhannya. Pada bagian busana, warna putih melambangkan kesucian diri secara lahir dan batin ketika bertemu dengan Rasulullah, keikhlasan dalam memanjatkan doa dan salawat, dan kejujuran terhadap segala hal. Sedangkan kain sarung dan kopyah melambangkan sikap kesederhanaan seorang hamba dan sikap takżimnya seseorang kepada yang lebih dihormati.

Meski belum semua jamaah Syekher Mania memahami simbol pada seni hadrah, akan tetapi melalui penelitian ini, diharapkan orang-orang yang semula tidak mengerti akan makna seni hadrah, menjadi lebih memahami esensi yang ada padanya. Jika sudah begitu, tentu mereka akan selalui termotivasi untuk ikut serta dalam majelis salawat dengan hati yang ikhlas dan khusyuk. Terakhir, yang terpenting dari sebuah proses interaksi dan komunikasi simbolik pada majelis Ahbaabul Musthofa adalah jamaah Syekher Mania memiliki pemahaman dan pedoman dalam berperilaku sesuai ajaran Nabi Muhammad SAW, sehingga dapat menerapkan pesan-pesan dakwah tersebut ke dalam perilaku kesehariannya. 


\section{Referensi}

Azis, Abdul. 2006. Jelajah Dakwah.Yogyakarta: Gama Media.

Aziz, Moh Ali. 2016. IImu Dakwah, J akarta: Penerbit Kencana.

Bakar, Abdul Latif Abu. 2006. "Aplikasi Teori Semiotika dalam Seni Pertunjukan”, Journal Etnomusikologi, vol. 2: 1.

Departemen Agama Rl. 2011. Al-Qur'an dan Terjemahnya. Jakarta: Cahaya Qur'an. Emzir. 2010. Metodologi Penelitian Pendidikan Kualitatif dan Kuantitatif. Jakarta: Rajawali Pers.

Ilahi, Wahyu. 2010. Komunikasi Dakwah. Bandung: PT. Remaja Rosdakarya.

Majelis Tertinggi Urusan Keislaman Mesir. 2007. Sunnah-sunnah Pilihan. Bandung: Angkasa Bandung.

Morissan. 2013. Teori Komunikasi. Surabaya: Ghalia Indonesia.

Mun'im, Abdul. 2015. Seni Rebana Hadrah Media Pendidikan Spiritual Mengenal Rasulullah. Skripsi. Kudus: Jurusan PAI STAIN Kudus.

Nasr, Seyyed Hossein. 2003. Ensiklopedi Tematis SPIRITUALITAS ISLAM: Manifestasi. Jakarta:

Mizan.

Najib, Abdul. 2017. Cinta Rasul dan Makna Simbol-simbol dalam Seni Hadrah Jawa Timur. Tesis. Surabaya: Program Pascasarjana UIN Sunan Ampel.

Qardhawi, Yusuf. 2000. Seni dan Islam. Bandung: Pustaka Hidayah.

Samiy, Mahmud. 1992. 70 Shalawat Pilihan. Yogyakarta: Pustaka Hidayah. Spradley, James P. 2006. Metode Etnografi. Yogyakarta: Tiara Wacana. Sutrisno. 2016. Pendidikan Karakter Melalui Seni. Yogyakarta: Pustaka Pelajar. 